Tribhuvan University Journal

Vol. 35, No. 1: 163-180, June, 2020

Research Directorate, Tribhuvan University,

Kathmandu, Nepal

DOI: https://doi.org/10.3126/tuj.v35i1.35879

\title{
PATTERN OF FOREIGN TRADE IN NEPAL
}

\author{
Sadan Kumar Bhagat \\ Associate Professor, Faculty of Management, Rajarshi Janak University, \\ Janakpurdham, Dhanusha, Nepal. \\ Corresponding author: bhagat.sadan@gmail.com
}

\begin{abstract}
Most of the countries in the world strengthen their economic and political power with the help of foreign trade and it is advantageous for both importing and exporting countries. The situation of foreign trade is not good in Nepal. Nepal has imported almost 15 times greater than its export amount in Fiscal Year 2018/19. The import amount of only petroleum products was 2.62 times greater than its total export amount. The major contributors of foreign trade were India and China which covered 64.70 percent and 13.70 percent market share respectively during FY 2018/19. The objectives of this study were to examine the situation of foreign trade in Nepal, to highlight its positive aspects and to analyze the problems along with some measures to resolve the problems. To examine the situation of foreign trade in Nepal secondary data have been collected from government publications and analyzed after presenting in tables. Likewise, a cross-section of 50 respondents from various cities have been interviewed to collect primary data. Nepal was always in trade deficit which was increasing every year. Remittance inflow from migrant labors was a major source of foreign exchange which covered the payment of imported goods. The problems of foreign trade were landlocked country, transit and transport problems, illegal import-export, low value addition exportable commodities, incompetent Nepalese products in terms of cost and quality, poor physical infrastructure, industrial dependency on imported raw and intermediate materials, procedural problems created by foreign countries in the import-export of products, administrative hurdles etc.
\end{abstract}

Keywords: Transit - open border - trade deficit - remittance inflow - infrastructure - handicrafts - petroleum products - hydro-electricity - modern technology.

\section{INTRODUCTION}

Business is the foundation for the development of a nation. International trade is the purchase, sale or exchange of goods and services 


\section{PATTERN OF FOREIGN TRADE IN NEPAL}

across the nation. It provides many advantages to both importing and exporting countries. Foreign trade is conducted to get economic as well as non-economic benefits. It is a tool through which the country can strengthen its economic and political power.

United States of America and China are live examples of $21^{\text {st }}$ century. Twenty-five years ago the economic condition of Singapore, Thailand, Taiwan, South Korea etc. was not good but these countries have gained economic prosperity through international trade. Nepal entered into the international trade regime after assessing the membership of WTO in the year 2004 which has opened various opportunities for the trade promotion of goods and services through multilateral trade agreements (Khanal 2016). However, Nepal could not get benefit of international trade and Nepal still remains one of the poor countries in the world. Nepal witnessed gradual shift from fully agrarian economy to semi modern system in recent years. In fact, agricultural progress is normally a prerequisite for industrial development. In a relatively closed economy, one of the most important preconditions of industrial expansion is the achievement of a rate of increase in agricultural productivity that exceeds the concurrent rate of increase in the demand for food. Rising agricultural productivity supports and sustains industrial development (Bhagat 2008).

The least developed countries including Nepal are experiencing many problems of industrialization such as the small size of the market, the traditional agriculture sector, deficiency in infrastructure, lack of capital, unawareness of industrial potential and so on (Pradhan 1979).

Nepal suffers from trade loss and its deficit is increasing gradually. It is time for Nepal to think about trade deficit and initiate measures to increase internal production and core competency so that it can enlarge its trade base (Sharma 2016).

Foreign trade encompasses many aspects in relation to various countries. For countries importing products, the benefit is that they get goods or services they cannot produce enough. Likewise, for the exporter, trade offer both goods and services as well as money with which to purchase goods/services from other countries. Foreign trade also helps economy by creating jobs, foreign direct investment, technology transfer etc.

No one country in the world is fully self-reliant. Each country has to import some goods/services which is scarce in own country. Rich and developed countries import less and export more, whereas poor/least 
developed countries import more and export less. When the domestic production is not enough or the product is not according to taste and preference of the consumers or production cost is too high, import of product becomes necessary and compulsion to fulfill the internal demand. Nepal is no exception in this case.

\section{OBJECTIVES AND METHODOLOGY}

- The objectives of the study are as follows:

- To examine the situation of foreign trade in Nepal.

- To highlight the positive aspects of foreign trade in Nepal.

- To analyze the problems of foreign trade in Nepal and suggest some measures to resolve problems.

To examine the situation of foreign trade in Nepal both primary and secondary data were used. The secondary data of import, export, balance of trade and remittance inflow were collected and compiled from government publications such as Economic Survey, Nepal Rastra Bank publications and reports, Central Bureau of Statistics, Department of Customs, Department of Foreign Employment, Department of Industry, Trade Promotion Centre etc. Similarly, various journals, newspapers, unpublished research reports, dissertations, books and websites were used to collect data of ten fiscal years from Fiscal Year 2009/10 to Fiscal Year 2018/19. The collected data have been presented in different tables and analyzed.

Descriptive research design was adopted in this study to assess the views of manufactures, importers, exporters, general people (consumers living in Nepalese territory), government officials, customs clearing agents, experts and politicians. Primary data were generated through in-depth interview with concerned persons. The study area and population were whole country however, due to the limitation of time and resources only five major cities (Kathmandu, Hetauda, Birgunj, Janakpur and Biratnagar) were selected for the purpose of survey and primary data collection. The population size was large and there were all together 3638 manufacturers/ producers (manufacturing, agro and forestry, and mineral based industries), 21,600 importers, 1893 exporters, 169 customs clearing agents throughout the country and 343 government officials working in customs offices of Kathmandu, Birgunj, Janakpur and Biratnagar. In spite of large number of population and selected five major cities only fifty persons were selected and consulted on the basis of Judgmental Sampling including ten manufacturers/ 


\section{PATTERN OF FOREIGN TRADE IN NEPAL}

producers, ten consumers (general people), five importers, five exporters, five experts, five politicians of various parties, five government officials and five customs clearing agents. The qualitative data were collected by in-depth interview and analyzed manually by using percentage. Survey questionnaire was given to 60 persons but only 50 respondents had finally replied. The sample comprised of a cross-section of 50 respondents including men and women and the interviews were conducted in Kathmandu, Birgunj, Hetauda, Janakpur and Biratnagar.

\section{FOREIGN TRADE SITUATION IN NEPAL}

The foreign trade of Nepal was virtually confined to India up to late 1950's. More than 90 percent of her import and export were carried with India alone. Over the years there have been significant directional changes in her exports as well as imports. The number of countries with whom Nepal has developed trade relations has considerably increased (Karna 1982). Due to the impact of trade liberalization and globalization, considerable success has been achieved in reducing the concentration of Nepalese foreign trade in Indian and Chinese markets. Nepal has now foreign trade with more than 150 countries and she has followed the policy of country and commodity diversification.

Due to the difficulties created by the COVID-19 pandemic, the entire production, manufacturing and supply chain has been negativity affected. The slowdown in global economy looks to severely impact economic growth, employment, prices and international trade and has also seriously affected Nepali economy (MoF 2019/20).

Table 1 and 2 (Annex I and II) reveal situation of foreign trade and remittance inflow in Nepal from Fiscal Year 2009/10 to Fiscal Year 2018/19. Total foreign trade of Nepal was Rs. 435.15 billion in FY 2009/10 and share of import was Rs. 374.33 billion whereas share of export was Rs. 60.82 billion only. The balance of trade was negative by Rs. 313.51 billion. The remittance inflow from foreign employment was Rs. 231.73 million which helped to manage trade deficit amount and foreign currency payment. Nepal had Rs. 177.12 billion trade deficit with India and Rs. 136.39 billion trade deficit with China and other countries. Out of total trade, India had 59.08 percent share whereas China and other countries' share was 40.92 percent. During FY 2009/10 export decreased by 10.16 percent whereas import increased by 31.59 percent in comparison to previous FY 2008/09. 
The trade with India increased by 26.38 percent. Similarly, the trade with China and other countries also increased by 19.72 percent in FY 2009/10.

The total foreign trade of Nepal increased up to Rs. 460.52 billion and share of import was Rs. 396.18 billion whereas the share of export was Rs. 64.34 billion in FY 2010/11. The balance of trade was negative by Rs. 331.84 billion. During FY 2011/12 the total foreign trade increased to Rs. 535.93 billion, import was Rs. 461.67 billion (16.53 percent more than FY 2010/11) and export also increased up to Rs. 74.26 billion (15.42 percent greater in comparison to FY 2010/11). The trade deficit was Rs. 387.41 billion and remittance inflow was Rs. 359.55 billion. Total share of India was Rs. 349.01 billion and share of China along with other countries was 186.92 billion in FY 2011/12 which exhibited poor condition of Nepalese foreign trade. The trade deficit was increasing every year.

The total foreign trade of Nepal increased by 18.23 percent in FY 2012/13. The total export increased by 13.58 percent but total import increased by 20.59 percent which led to negative balance of trade up to Rs. 479.82 billion. Similarly, during FY 2013/14 total foreign trade of Nepal increased by 27.25 percent and it reached to Rs. 806.36 billion. The total import was 714.37 billion and total export was Rs. 91.99 billion only. The amount of import was almost 8 times greater than export and trade deficit was Rs. 622.38 billion which had very negative impact on Nepalese economy. The trade deficit with India, China and other countries were Rs. 418.34 billion, Rs. 70.48 billion and Rs. 133.56 billion respectively. Similarly, share of India, China and other countries were 66.67 percent, 09.44 percent and 23.89 percent respectively in FY 2013/14. This figure exhibited that India had greater influence on Nepalese foreign trade.

During FY 2014/15 the total foreign trade of Nepal increased by 06.65 percent and reached to Rs. 860.01 billion in which foreign trade with India, China and other countries were Rs. 547.53 billion, Rs. 102.40 billion and Rs. 210.08 billion respectively. There was 08.44 percent increase in import and 07.25 percent decrease in export in comparison to FY 2013/14. Trade deficit was Rs. 689.37 billion.

The devastating earthquake of $25^{\text {th }}$ April 2015 significantly influenced foreign trade of Nepal. After earthquake of 2015, the construction and repair of damaged infrastructure needed more construction materials, so greater change was seen in total foreign trade of Nepal in FY 2016/17. The total foreign trade amount was Rs. 1063.16 billion in FY 2016/17 which 


\section{PATTERN OF FOREIGN TRADE IN NEPAL}

was 26.01 percent higher than previous Fiscal Year 2015/16. There was 04.19 percent increment in export and 27.99 percent increment in import too. Trade deficit was Rs. 917.06 billion.

There was greater increment in total foreign trade in FY 2017/18 and it reached to Rs. 1324.46 billion (24.58 percent higher than FY 2016/17) and trade deficit reached to Rs. 1161.20 billion. Export increased by 11.75 percent only whereas import increased by 25.52 percent. The growth in imports had superseded the growth in exports. The structure of total share of Nepalese foreign trade was India dominated and India had 64.66 percent share, other countries had 23.07 percent and China had 12.27 percent share during FY 2017/18.

A study report of Nepal Rastra Bank published on Feb., 2020 regarding 'Trend of Nepalese Foreign Trade' showed 14.46 percent increment in total foreign trade and the amount was Rs. 1516 billion in FY 2018/19. Total export was Rs. 97 billion (18.83 percent higher than previous FY 2017/18) and total import was Rs. 1419 billion (14.17 percent higher than FY 2017/18). Similarly, trade deficit was Rs. 1322 billion which showed very weak position of Nepalese foreign trade and it was 13.85 percent higher than previous FY 2017/18.

During FY 2018/19 the total foreign trade of Nepal increased by 14.44 percent and reached to Rs. 1515.65 billion in which foreign trade with India, China and other countries were Rs. 980.64 billion, Rs. 207.64 billion and Rs. 327.37 billion respectively. There was 18.97 percent increase in export and 14.14 percent increase in import in comparison to FY 2017/18. The trade deficit increased to Rs. 1321.43 billion which was 13.80 percent higher than FY 2017/18. The remittance inflow amount was Rs. 879.3 billion and major portion of trade deficit was borne by foreign currency earned from foreign employment. The amount of import was almost fifteen times greater than export in Fiscal Year 2018/19. Thus the structure of Nepalese foreign trade is weak and balance of foreign trade is highly negative.

The trade deficit of Nepal has surged with the increase in trade openness subsequent to the adoption of trade liberalization. The growth of merchandise exports has been lower than that of import. The remittance inflow has stood as a major pillar for overall balance of payment, and external sector's stability. Remittance inflow has remained as a major source for foreign exchange. The robust external sector has helped achieve 
overall economic stability. The foreign exchange reserve level has been sufficient to cover the imports. The balance of payment remained in surplus even after receiving several supply related shocks including devastating earthquake and border obstruction (MoF 2016/17).

\section{POSITIVE ASPECTS OF FOREIGN TRADE IN NEPAL}

The balance of foreign trade is negative in Nepal and it has been increasing. However, the positive aspects of foreign trade in Nepal are highlighted in the following section.

- The main source of government revenue is foreign trade which includes Customs Duty, Value Added Tax (VAT), Excise Duty etc. The contribution of foreign trade revenue was more than 40 percent in total revenue during FY 2017/18. During survey all of the government officials of Nepalese customs offices and customs clearing agents opined that a major part of government revenue had been earned through foreign trade and India had greater share. The imported petroleum products, transport equipment and parts had major contribution in government revenue. Further, they had the opinion that contribution in revenue could be increased to some extent, if illegal import-export was controlled in Nepal-Indo borders.

- The foreign trade which was limited between India and Tibet (China) is now diversified among more than 150 countries. Nepal has signed different regional and international organization' agreement so the horizon of business is extended. Nepal is not bound with India and China only for foreign trade. Foreign trade is not limited up to goods trade rather it includes service trade too. Business connection has given space for cultural, educational and technological exchange between countries. More than 90 percent Nepalese industrialists opined that in spite of heavy trade deficit, there was no way except import of goods to operate the Nepalese industries and to give pace to the economy.

- The total demand for country cannot be fulfilled by internal production in present situation so import becomes the solution of deficit supply. Proper and regular supply of commodities makes the life of people easier and comfortable. Living standard of people is improved by using imported goods and services such as motor car, computer, mobile, internet facilities, medicine, health equipment, electrical items etc. 


\section{PATTERN OF FOREIGN TRADE IN NEPAL}

- The products of cottage and small industries are mostly exported to foreign countries. Thus survival and growth of such industries largely depend on export.

- Some Nepalese products are popular in foreign markets like woolen carpet, pashmina, readymade garments, handicraft products etc. These domestic products have occupied space in foreign markets and some other products have also got chance to enter into foreign market along with these famous products. Thus Nepalese products are recognized and preferred in various countries. The promotion of export helps to earn foreign currency and extend the employment opportunities.

- The share of capital goods is remarkable in total import. Increase in import of capital goods leads to negative balance of foreign trade. Nevertheless, import of capital goods helps to increase domestic production, import substitution and raise employment opportunity as well as economic development of the nation.

- Some natural resources are so far not available in Nepal so there is no way except import of such products like petroleum products, natural gas, M.S. billet, aluminum ingot, coal, gold, silver etc. Almost 76 percent experts opined that the government of Nepal had a plan to extract its natural resources but there was problem of capital, know-how, skilled manpower, latest technology and plant and machinery. These should be imported for the commencement of extraction and refinement of extracted materials.

- The Nepalese industries are still using obsolete technology, do not run in full capacity and dependent on imported raw materials. The cost of production therefore, remains high. In the era of globalization and trade liberalization, the same products are imported at low cost. Further, the domestic production is not sufficient to fulfill domestic demand. Thus, only one option remains for Nepal to import such commodities to fulfill the needs.

- Optimum utilization of resources is possible through foreign trade. Nepal is rich in natural water resources and it can earn foreign currency by exporting surplus hydro-electricity to two densely populated large countries, India and China.

- The foreign trade allows to bring skilled manpower, technology and high quality raw materials at low price in the home country. Thus, Nepalese 
manufacturers can improve their quality of products by importing skilled manpower, latest technology and high quality raw materials. As a result, the high quality goods can be supplied at comparatively low prices in domestic market as well as foreign markets.

\section{PROBLEMS OF FOREIGN TRADE} sections.

The problems of foreign trade are analyzed in the following

- Nepal is a land-locked country and 83 percent land is covered with high mountains and hills. Transit and transport problems are most considerable obstacles in the field of foreign trade. India is coming to be interfered with unnecessary obstacles in using our transit right. The customs related requirements in the ports, load and unload of the materials from the ship take long time. As a result, Nepalese businessmen have to pay a large amount of demurrage that increases the cost of materials. The sea ports of India are available with the conditions. The long distance from the ports to our border results transportation cost hikes. Nepal mostly depends on the road transportation. The highways are limited and narrow and the conditions of roads as well as vehicles are miserable in hilly areas.

- Transit and transportation problems increase the cost of Nepalese businessmen which ultimately reduce the competitive strength in both foreign and domestic markets. More than 95 percent importers and exporters had the bitter experience with the dealings of Indian customs officials, port authorities, transporters and security personnel regarding creation of unnecessary obstacles, demurrage, high transportation fare, long queue for the availability of railway rack and containers, procedural problems, too much documentary requirement etc.

- Nepal-Indo open border is $1880 \mathrm{~km}$. long and it is very cumbersome to control informal and illegal import-export. There is free movement of people from both sides. Customs offices are established in specified places and the rest part of the border is open and without security check. The residents of both countries take benefit of open border. This has created negative impact on Nepalese economy.

- Continuous research, development and innovations in the developed countries have equipped them with modern technology and produce technology intensive standard commodities. The mode of international 


\section{PATTERN OF FOREIGN TRADE IN NEPAL}

trade for them has been shifted from commodities trade to technology trade. In the case of Nepal, many exportable commodities are either primary or handmade, which contribute low value addition. Lack of raw materials, skilled manpower and limited capital are the prominent causes for weakening industrial production of Nepal.

- Poor physical infrastructure of Nepal is also one of the major problems of foreign trade. Lack of roads, bridges, transmission lines, warehouses, industrial areas, quarantine centers, well-equipped customs offices and lack of other services such as bank, insurance, security, etc. are directly or indirectly responsible in increasing the cost of production.

- The topographical situation is also not favorable. Mountainous region cover 15 percent and hilly region cover 68 percent part of total land of Nepal where transportation (roads, vehicles, bridges) network is very poor. Life is tough for those people who live in remote areas. Their contribution is low in foreign trade.

- Some Nepalese industries are dependent on imported raw materials. The future of such industries depends on the regular supply of raw materials at reasonable cost and customs duty. When scenario is changed negatively, production and cost of such industries are adversely affected. If such finished products are exported, it becomes compulsion for Nepal to increase import of raw materials in the same ratio to fulfill export demand.

- Procedural problems also create hurdle in foreign trade of Nepal. Too much documentary requirements, complicated procedures for transit, transport and inadequate transit facility all caused delay in border crossing. Foreign officials put administrative hurdles for Nepalese goods. Some countries put import quota for Nepalese products in their countries which create barrier in the export of Nepalese goods.

- Nepal has been doing foreign trade with more than 150 countries. But the major parts of trade have been concentrated with India and its share was 64.70 percent in FY 2018/19. The second large business partner was China and its share was 13.70 percent. Rest 21.60 percent trade share was concentrated with more than 148 other countries in the world. The consumption of various imported products has been increasing day by day. The payment of imported commodities is mostly borne by foreign currency earned through remittance sent by Nepalese labors working abroad. Management of deficit foreign trade is in wrong 
direction and excess dependence on remittance is not a permanent and perfect solution of Nepalese economy.

- The demand for Nepalese people cannot be fulfilled by domestic production because of limited number of industries and low production capacity. Nepal imports almost 15 times greater than its export amount.

\section{MEASURES TO MANAGE FOREIGN TRADE}

Some measures to manage foreign trade and resolve the problems are as follows:

- The balance of foreign trade is negative and movement of goods is mostly one sided so Nepal is trapped in 'black hole effect'. If Nepal cannot apply counter balancing force to get rid of 'black hole effect' the Nepalese economy will be damaged. Nepal should decrease import and increase export as far as possible. During the survey 67 percent politicians and leaders had the opinion that policy of foreign trade should be reviewed according to change in time. An effort should be made to increase domestic production of import substitution goods and increase in export of high value addition commodities.

- Nepal should try to attract foreign direct investment (FDI), knowhow and technology and exploit its resources to the optimum level. These will help to increase domestic production and employment opportunities and increase production of import substitution goods. The positive impact of such effort will be seen as reduction in trade deficit and increment in foreign currency deposit.

- In the absence of warehouse (cold storage), transportation medium and road network, agricultural and horticulture produce of hilly and remote areas cannot reach to Nepalese market. On the other side, the same produce is imported from India and China. The government should try to increase road network, transmission lines, telecommunication facilities, warehouses (cold storage), bank and insurance facilities to reach such produce in Nepalese as well as foreign markets.

- Nepal expended 2.62 times greater amount in petroleum products than its total export amount. Thus, Nepal used a huge amount of foreign currency to import such items. It is must for Nepal to exploit natural resources and produce petroleum products. 


\section{PATTERN OF FOREIGN TRADE IN NEPAL}

- By the utilization of hydro-electricity the demand for petroleum products can be substituted. Use of electric vehicles, electric trains, induction stove, electric heater and production of electricity through wind and solar energy will certainly reduce the consumption of petroleum products. Further, this will help to reduce air pollution and trade deficit too.

- The developed countries are well equipped with modern technology and they produce technology intensive commodities. In the case of Nepal, the progress being made by introducing latest technology in manufacturing industries is sluggish and still far behind the other competing countries. Nepal has to do a lot to make production based on modern technologies comparable to the international standard. The manufacturing industries should prioritize to produce high value addition commodities by introducing cost effective latest technology.

- Some of the polices concerned with the production, import and export should be reviewed from the perspective of production and export. Similarly, various Nepal Acts such as Company Act, Industrial Business Act, Foreign Direct Investment and Technology Transfer Act, Customs Act etc. should be reviewed and made adaptable according to the new environment.

- The government should encourage the private sector to get involved in production activities along with attracting the foreign investment in establishing industries. Nepal has advantages of cheap raw materials, low wage workers, suitable environment and large neighbors having huge market potential so it is essential to identify strength and capitalize on it to increase export and decrease import.

- More than 81 percent consumers (general people) opined that imported products were generally better in quality and durable also (except Chinese goods) so they liked imported goods. However, they had no negative view towards domestic products. Most of them had been using domestic products. Further they argued that Nepal had need to take initiatives to promote export of agro and herbal based products and handicrafts in which it had a comparative advantage.

- The trend of Nepalese foreign trade is India centered. India has almost 65 percent share in Nepalese foreign trade. Excess dependence on single country is not safe and Nepal has bitter experience of Indian border obstructions. Nepal should make strategy to reduce import from 
India and produce import substitution commodities in own country. Further, Nepal can supply large volume of surplus hydro-electricity to India and nearby countries in coming time. Extraction of minerals, coal, petroleum products, natural gas etc. can make country self-reliant and a large volume of import can be substituted.

- The provisions of industrial districts, special economic zones, relaxation in tax and low interest rate on bank loan for export based industries are some tools through which production and export can be increased. To increase the foreign trade and diversification of trade, the government should create an environment to encourage private sector to play a principal role in the industrialization of the country so that Nepal can move on the path of self- sufficiency.

- The government should facilitate the domestic producers in terms of better supply chain management, logistic support, bonded warehouse, subsidies in fertilizer, irrigation etc. Similarly, domestic industries should be facilitated in terms of subsidies in bank loan, insurance premium, plant and machinery etc. In addition, government should also help these industries by providing preference of special economic zones, capacity enhancement programs, skill development programs for unskilled and semi-skilled unorganized work-forces.

\section{CONCLUSION}

The foreign trade of Nepal is suffering from the problem of trade deficit i.e. low volume of export and high volume of import. The size of import was almost fifteen times greater than export in FY 2018/19. The major problems of foreign trade are landlocked feature of the country, open border with less security, poor physical infrastructural and technological status, poor access to market, lack of raw materials, scarcity of skilled manpower, inadequate capital and high cost of production in manufacturing industries. Similarly, other problems are inadequate market information, transit and transport problems, cumbersome ports and customs related formalities, production and export of low value addition commodities, dependency of industries on imported raw and intermediate materials etc. The opinion survey of government officials working in Nepalese customs offices and customs clearing agents conclude that major portion of government revenue has been earned through foreign trade and India has greater share. The contribution of government revenue can be increased by controlling smuggling in Nepal-Indo borders. More than 90 percent 
industrialists (manufacturers) opine that in spite of heavy trade deficit, there is no option of import of goods at present situation. Seventy-six percent experts have the opinion that natural resources should be extracted as soon as possible so that import can be substituted. More than 95 percent Nepalese importers and exporters have bitter experience while dealing with Indian officials as they mostly face unnecessary obstacles. Similarly, 67 percent politicians and leaders express that foreign trade policy should be reviewed and domestic production should be increased to substitute import and export high value addition commodities as far as possible. More than 81 percent consumers (general people) prefer imported goods however they have no negative view towards domestic products as they have been using various domestic products since long time.

Previous research findings supported this study regarding increasing trade deficit and dependency on imported goods. Further, trade deficit amount is managed by foreign currency earned from foreign employment remittance. We should try to balance the gap of export and import. Poor condition of physical infrastructure should be improved. A large amount of foreign currency is used to import petroleum products so its use should be minimized by using hydro-electricity and initiate to extract natural resources. Our industries should be rejuvenated with introducing cost effective latest technology. The policies concerned with the production, import-export, FDI should be reviewed according to new environment. The private sectors should be encouraged to attract foreign investment in establishing industries. Dependence on India should be minimized by increasing domestic production and import substitution goods as far as possible. Attempt should be made to increase generation of hydro-electricity power and if there is surplus, it should be exported to India, China and other nearby countries which will help to reduce foreign trade deficit. Further it will be a milestone to reduce air pollution too.

\section{REFERENCES}

Acharya, K.P. (2018). Nepalko byapar ghata ra antarnihit jokhim. Mirmire, Journal of Nepal Rastra Bank, 47(1):1-14.

Acharya, P.P. (2018). Nepal ko byapar ra sambhawanaharu. Arunodaya, Nepal Rastra Bank Karmachari Sangh, 24(22):196-201.

Adhikari, D. (2018). Impact of exchange rate on trade deficit and foreign exchange reserve in Nepal: An empirical analysis. NRB Economic Review, 30: 43-45. 
Bhagat, S.K. (2008). Marketing of agro based products in Nepal: With special reference to cigarette and sugar. Unpublished $\mathrm{PhD}$ dissertation. Faculty of Management, Tribhuvan University, Kirtipur, Kathmandu, Nepal, p. 10.

Bhandari, K. (2019). Nepalko baideshik byaparka mahatwapurna suchakharu, yes chetraka uplabdhi, samasya ra sambhawanaharu. Mirmire, Journal of Nepal Rastra Bank, 47(3): 30-48.

Bhatta, G.R. (2019). International trade and exchange rates: Issues and challenges for Nepal. FIEUN Mirror, Financial Institute Employees Union of Nepal, pp.245-251.

Chaulagain, M.K. (2014). Nepal ko baideshik byapar: Ek sankshipta paridrishya. Arunodaya, Nepal Rastra Bank Karmachari Sangh, 19(17): 242-248.

MoF. (2017). Economic survey, FY 2016/17. Government of Nepal, Ministry of Finance, Kathmandu.

MoF. (2019). Economic survey, FY 2018/19. Government of Nepal, Ministry of Finance, Kathmandu.

MoF. (2020). Economic survey, FY 2019/20. Government of Nepal, Ministry of Finance, Kathmandu.

MoI. (2020). Industrial statistics, FY 2019/20. Government of Nepal, Ministry of Industry, Commerce and Supplies, Kathmandu.

Hada, G.B. (2015). Nepalma baideshik byaparko mahatwa tatha bartaman awastha. Aarthik Mimansa, Nepal Bitteeya Sanstha Karmachari Sangh, 10: 11-24.

Karna, S.L. (1982). An analysis of Nepal's export pattern to overseas countries. A Research Report submitted to Faculty of Development Centre. Ahmedabad, India: Indian Institute of Management. p.30.

Khanal, S.P. (2016). WTO and Nepal's commitment towards GATS: An overview. Aarthik Mimansa, Nepal Bitteeya Sanstha Karmachari Sangh, 11:215-222.

Khatri, M.B. (2017). Trade war between China and USA: Implications to Nepal. The Economic Journal of Nepal, 40 (1,2,3\&4): 53-66.

NRB. (2020). Nepalko baideshik byapar prawirti. A Research Report submitted to Nepal Rastra Bank, Kathmandu. https://www.nrb.org. np, Accessed: 10.04.2020. 
Neupane, R.P. (2019). Protectionism: A new wave in international trade. Arunodaya, Nepal Rastra Bank Karmachari Sangh, 25(23): 355359.

Pradhan, I.K. (1979). X-ray of small scale industries in Nepal: Problems, prospects and future scope. ISDOC. Kathmandu, Nepal: Industrial Services Centre. p.1.

Sapkota, K.B. (2016). Impact of world trade organization on demand pattern and opportunities to tea farmers in Nepal. Tribhuvan University Journal, $\mathbf{X X X}$ (2): 73-88.

Sharma, B. (2016). Theories of international trade and Nepal's trade position: A critical assessment. Mirmire, Journal of Nepal Rastra Bank, 45(3): 226-233.

Subedi, D. (2019). Nepal's foreign aid, international trade employment, foreign investment related policies: Their features, objectives, strengths, weaknesses and issues. FIEUN Mirror, Financial Institute Employees Union of Nepal, (pp.256-264).

Thapa, A.B. (2016). International trade of Nepal: Current issues, problems and opportunities. Rupantaran, Journal of Nepal Rastriya Karmachari Sangathan,7(7): 274-282.

Timsina, M.P. (2016). Foreign trade of SAARC members. Nepal Rastra Bank Samachar, 61: 179-185.

Timsina, M.P. (2016). Nepal's foreign trade: Problems and prospects. Rupantara, Journal of Nepal Rastriya Karmachari Sangathan, 7(7): 315-325. 


\section{(ANNEX-I)}

Table 1: Situation of Foreign Trade and Remittance Inflow in Nepal from FY 2009/10 to FY 2018/19 (Rs. in billion)

\begin{tabular}{|c|c|c|c|c|c|c|c|c|c|c|}
\hline \multirow{3}{*}{ Description } & \multicolumn{10}{|c|}{ Fiscal Years } \\
\hline & 2009 & 2010 & 201 & 2012 & 2013 & 2014 & 2015 & 2016 & 2017 & 2018 \\
\hline & 2010 & 2011 & 2012 & 2013 & 2014 & 2015 & 2016 & 2017 & 2018 & 2019 \\
\hline Export FOB & 60.82 & 64.34 & 74.26 & 76.92 & 91.99 & 85.32 & 70.11 & 73.05 & 81.63 & 97.11 \\
\hline India & 39.99 & 43.36 & 49.62 & 51.00 & 59.61 & 55.87 & 39.49 & 41.45 & 46.60 & 62.73 \\
\hline China & - & - & - & 2.09 & 2.84 & 2.23 & 1.68 & 1.70 & 2.88 & 2.11 \\
\hline Other countries & 20.83 & 20.98 & 24.64 & 23.83 & 29.54 & 27.22 & 28.94 & 29.90 & 32.15 & 32.27 \\
\hline Import CIF & 374.33 & 396.18 & 461.67 & 556.74 & 714.37 & 774.69 & 773.59 & 990.11 & 1242.83 & 1418.54 \\
\hline India & 217.11 & 261.93 & 299.39 & 367.03 & 477.95 & 491.66 & 477.21 & 633.67 & 809.81 & 917.91 \\
\hline China & - & - & - & 62.45 & 73.32 & 100.17 & 115.69 & 127.24 & 159.64 & 205.53 \\
\hline Other countries & 157.22 & 134.25 & 162.28 & 127.26 & 163.10 & 182.86 & 180.69 & 229.20 & 273.38 & 295.10 \\
\hline Balance of Trade & -313.51 & -331.84 & -387.41 & -479.82 & -622.38 & -689.37 & -703.48 & -917.06 & -1161.20 & -1321.43 \\
\hline India & -177.12 & -218.57 & -249.77 & -316.03 & -418.34 & -435.79 & -437.72 & -592.22 & -763.21 & -855.18 \\
\hline China & - & - & - & -60.36 & -70.48 & -97.94 & -114.01 & -125.54 & -156.76 & -203.42 \\
\hline Other countries & -136.39 & -113.27 & -137.64 & -163.43 & -133.56 & -155.64 & -151.75 & -199.30 & -241.23 & -262.83 \\
\hline Total Trade & 435.15 & 460.52 & 535.93 & 633.66 & 806.36 & 860.01 & 843.70 & 1063.16 & 1324.46 & 1515.65 \\
\hline India & 257.10 & 305.29 & 349.01 & 418.03 & 537.56 & 547.53 & 516.70 & 675.12 & 856.41 & 980.64 \\
\hline China & - & - & - & 64.54 & 76.16 & 102.40 & 117.37 & 128.94 & 162.52 & 207.64 \\
\hline Other countries & 178.05 & 155.23 & 186.92 & 151.09 & 192.64 & 210.08 & 209.63 & 259.10 & 305.53 & 327.37 \\
\hline $\begin{array}{l}\text { Total Trade } \\
\text { Share(In Percent) }\end{array}$ & 100.00 & 100.00 & 100.00 & 100.00 & 100.00 & 100.00 & 100.00 & 100.00 & 100.00 & 100.00 \\
\hline India & 59.08 & 66.29 & 65.12 & 65.97 & 66.67 & 63.66 & 61.24 & 63.50 & 64.66 & 64.70 \\
\hline China & - & - & - & 10.19 & 09.44 & 11.91 & 13.91 & 12.13 & 12.27 & 13.70 \\
\hline Other Countries & 40.92 & 33.71 & 34.88 & 23.84 & 23.89 & 24.43 & 24.85 & 24.37 & 23.07 & 21.60 \\
\hline Remittance Inflow & 231.73 & 253.55 & 359.55 & 434.58 & 543.29 & 617.28 & 665.06 & 695.45 & 755.06 & 879.3 \\
\hline
\end{tabular}

Sources:Economic Survey, 2019/20. 
180 PATTERN OF FOREIGN TRADE IN NEPAL

(ANNEX-II)

Table 2: Percentage Change in Situation of Foreign Trade and Remittance Inflow in Nepal from FY 2009/10 to FY 2018/19.

\begin{tabular}{|c|c|c|c|c|c|c|c|c|c|c|}
\hline \multirow{3}{*}{ Description } & \multicolumn{10}{|c|}{ Fiscal Years } \\
\hline & 2009 & 2010 & 201 & 2012 & 2013 & 2014 & 2015 & 2016 & 2017 & 2018 \\
\hline & 2010 & 2011 & 2012 & 2013 & 2014 & 2015 & 2016 & 2017 & 2018 & 2019 \\
\hline Percentage Change in Export & -10.16 & 05.79 & 15.42 & 13.58 & 19.59 & -07.25 & -17.82 & 04.19 & 11.75 & 18.97 \\
\hline Percentage Change in Import & 31.59 & 05.84 & 16.53 & 20.59 & 28.31 & 08.44 & -00.14 & 27.99 & 25.52 & 14.14 \\
\hline $\begin{array}{l}\text { Percentage Change in Import } \\
\text { from India }\end{array}$ & 33.66 & 20.64 & 14.30 & 22.59 & 30.22 & 02.87 & -02.94 & 32.79 & 27.80 & 13.35 \\
\hline $\begin{array}{l}\text { Percentage Change in Total } \\
\text { Trade }\end{array}$ & 23.56 & 05.83 & 16.38 & 18.23 & 27.25 & 06.65 & -01.90 & 26.01 & 24.58 & 14.44 \\
\hline $\begin{array}{l}\text { Percentage Change in Total } \\
\text { Trade with India }\end{array}$ & 26.38 & 18.74 & 14.32 & 19.78 & 28.59 & 01.85 & -05.63 & 30.66 & 26.85 & 14.51 \\
\hline $\begin{array}{l}\text { Percentage Change in Total } \\
\text { Trade with China }\end{array}$ & - & - & - & - & 18.00 & 34.45 & 14.62 & 09.86 & 26.04 & 27.77 \\
\hline $\begin{array}{l}\text { Percentage Change in Total } \\
\text { Trade with Other Countries }\end{array}$ & 19.72 & -12.82 & 20.41 & -19.17 & 27.50 & 09.05 & -00.21 & 23.60 & 17.92 & 7.15 \\
\hline $\begin{array}{l}\text { Percentage Change in } \\
\text { Remittance Inflow }\end{array}$ & 10.51 & 9.42 & 41.81 & 20.87 & 25.01 & 13.62 & 7.74 & 4.57 & 8.57 & 16.45 \\
\hline
\end{tabular}

Sources: $\quad$ Economic Survey, 2019/20.

Note: Data of percentage change is computed on the basis of Table 1 (Annex-I). 